\title{
Caldicellulosiruptor owensensis sp. nov., an anaerobic, extremely thermophilic, xylanolytic bacterium
}

\author{
Chi-Yu Huang, ${ }^{1}$ Bharat K. Patel, ${ }^{2}$ Robert A. Mah ${ }^{1}$ and Larry Baresi ${ }^{3}$ \\ Author for correspondence: Chi-Yu Huang. Tel: +1 310825 2569. Fax: +1 3107942106. \\ e-mail: cyhuang@ucla.edu
}

\footnotetext{
1 Department of Environmental Health Sciences, School of Public Health, University of California, Los Angeles, CA 90095-1772, USA

2 Faculty of Science and Technology, Griffith University, Nathan 4111, Brisbane, Australia

3 Department of Biology, California State University, Northridge, CA, USA
}

\begin{abstract}
An anaerobic, extremely thermophilic, xylanolytic, non-spore-forming bacterium was isolated from a sediment sample taken from Owens Lake, California, and designated strain $\mathrm{OL}^{\top}\left(\mathrm{T}=\right.$ type strain). Strain $\mathrm{OL}^{\top}$ had a Gramnegative reaction and occurred as short rods which sometimes formed long chains containing a few coccoid cells. It grew at 50-80 ${ }^{\circ} \mathrm{C}$, with an optimum at $75^{\circ} \mathrm{C}$. The $\mathrm{pH}$ range for growth was 5.5-9.0 with an optimum at about pH 7.5. When grown on glucose at optimal conditions, its doubling time was $7.3 \mathrm{~h}$. In addition to glucose, the isolate utilized sucrose, xylose, fructose, ribose, xylan, starch, pectin and cellulose. Yeast extract stimulated growth on carbohydrates but was not obligately required. The end products from glucose fermentation were lactate, acetate, ethanol, $\mathrm{H}_{2}$ and $\mathrm{CO}_{2}$. The $\mathrm{G}+\mathrm{C}$ content of strain $\mathrm{OL}^{\top}$ was $36.6 \mathrm{~mol} \%$. The $16 \mathrm{~S}$ rDNA sequence analysis indicated that strain $\mathrm{OL}^{\top}$ was a member of the subdivision containing Gram-positive bacteria with DNA G+C content of less than $\mathbf{5 5}$ mol\% and clustered with members of the genus Caldicellulosiruptor. Because strain $\mathrm{OL}^{\mathrm{T}}$ is phylogenetically and phenotypically different from other members of this genus, it is proposed to designate this isolate Caldicellulosiruptor owensensis sp. nov. Strain ${ }^{\top} L^{\top}$ is the type strain (= ATCC 700167').
\end{abstract}

Keywords: Caldicellulosiruptor owensensis, thermophile, xylanolytic bacterium

\section{INTRODUCTION}

Thermophilic and extremely thermophilic microorganisms have gained a great deal of attention recently (3). Enzymes from these micro-organisms are of special interest since they are not usually denatured by high temperatures and are even active at elevated temperatures $(3,35)$. Furthermore, members of the thermoanaerobic saccharolytic group may be commercially useful for producing chemicals and fuels such as ethanol and lactate from plant biomass (15).

Xylan is a major component of plant hemicellulose; after cellulose, it is the next most abundant renewable polysaccharide in nature. Several species of xylanolytic, thermophilic anaerobes have been isolated and identified as members the genera Clostridium, Thermoanaerobacter, Thermoanaerobacterium and Caldicellulosiruptor $(4,16,33)$. 16S rRNA sequence analysis of these four genera showed individual coherent clusters

The GenBank accession number for the $16 \mathrm{~S}$ rDNA sequence of strain $\mathrm{OL}^{\top}$ is U80596. in the subdivision containing Gram-positive bacteria with a DNA G + C content of less than $55 \mathrm{~mol} \%$ (26). The newly described genus, Caldicellulosiruptor, is assigned to the phylogenetic cluster ' $\mathrm{D}$ ' and is the least studied. The seven strains in cluster D were isolated exclusively from hot springs and all degrade cellulose. Of these, only Caldicellulosiruptor saccharolyticus (formerly designated Caldocellum saccharolyticus) was taxonomically validated (25).

We describe in this paper, a new extremely thermophilic, xylanolytic anaerobic bacterium isolated from sediments of Owens Lake, California, USA. Phenotypic and phylogenetic characteristics indicate that it is a new species of the genus Caldicellulosiruptor. We designated it Caldicellulosiruptor owensensis sp. nov.

\section{METHODS}

Sampling procedure. Sediment samples were collected from a small freshwater pond located within the dry Owens Lake bed in California. The samples were kept under anaerobic conditions in serum bottles, transported to the laboratory at UCLA at ambient temperatures, and stored at $4{ }^{\circ} \mathrm{C}$ until 

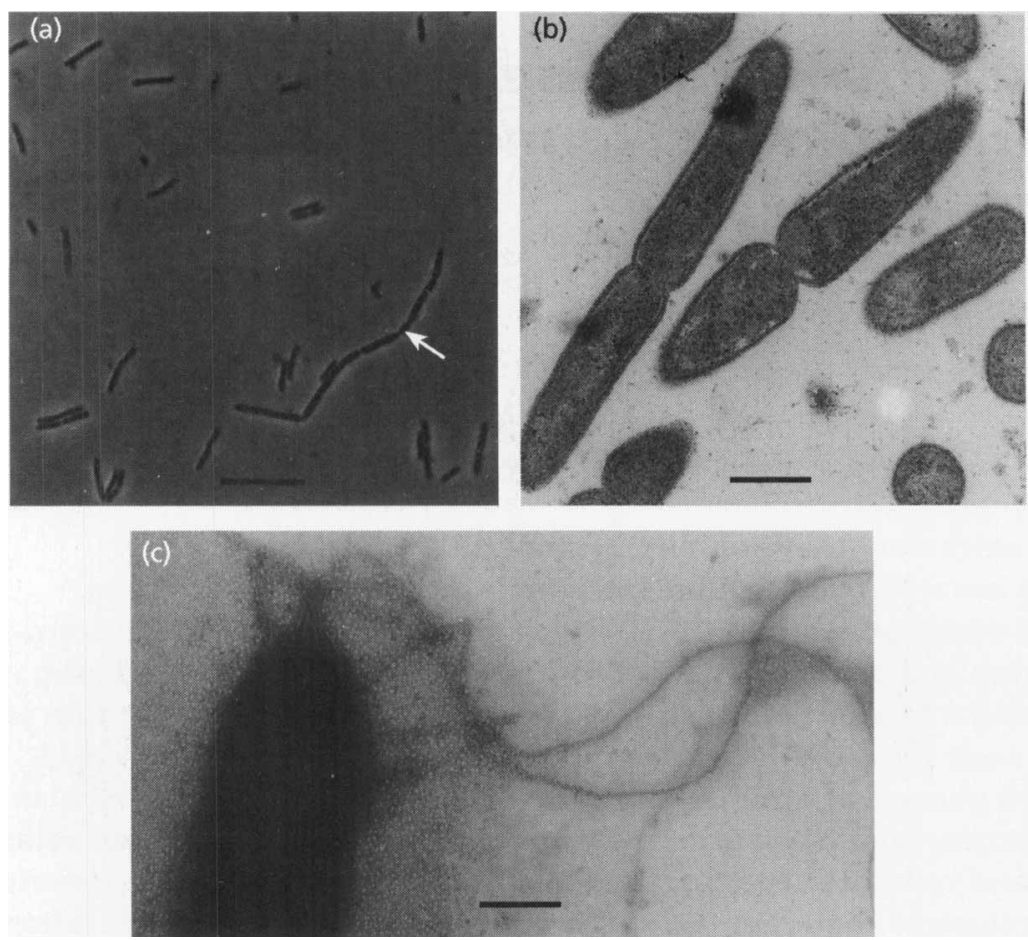

Fig. 1. (a) Phase-contrast photomicrograph of cells from exponential growth phase of strain $\mathrm{OL}^{\top}$. Cocci denoted by arrow. Bar, $10 \mu \mathrm{m}$. (b) Transmission electron micrograph of a thin section of whole cells of strain $\mathrm{OL}^{\mathrm{T}}$. Bar, $1 \mu \mathrm{m}$. (c) Transmission electron micrograph of negatively stained strain $\mathrm{OL}^{\top}$ showing the presence of lophotrichous flagella. Bar, $1 \mu \mathrm{m}$. used. The temperature and $\mathrm{pH}$ of the sample site was $32{ }^{\circ} \mathrm{C}$ and $9 \cdot 0$, respectively.

Enrichment and isolation. An enrichment culture medium modified from Angelidaki et al. (2) designated CBM was used. CBM consisted of (per litre distilled water) yeast extract (Difco), $1 \mathrm{~g}$; xylan, $5 \mathrm{~g} ; \mathrm{NH}_{4} \mathrm{Cl}, 1 \mathrm{~g} ; \mathrm{NaCl}, 0.1 \mathrm{~g}$; $\mathrm{MgCl}_{2} .6 \mathrm{H}_{2} \mathrm{O}, 0.1 \mathrm{~g} ; \mathrm{CaCl}_{2} .2 \mathrm{H}_{2} \mathrm{O}, 0.05 \mathrm{~g} ; \mathrm{K}_{2} \mathrm{HPO}_{4}, 0.4 \mathrm{~g}$; resazurin, $0.0005 \mathrm{~g} ; 1 \mathrm{ml}$ vitamin mixture, and $10 \mathrm{ml}$ trace mineral solution (10). The vitamin solution contained $(\mathrm{mg}$ $1^{-1}$ ): biotin, 2; folic acid, 2; pyridoxine hydrochloride, 10; thiamine hydrochloride, 5 ; riboflavin, 5 ; nicotinic acid, 5 ; DL-calcium pantothenate, 5 ; vitamin $\mathrm{B}_{12}, 0.1$; $p$-aminobenzoic acid, 5 ; and lipoic acid, 5 . The trace mineral solution contained (per litre): $\mathrm{H}_{2} \mathrm{SeO}_{3}, 0.01 \mathrm{~g} ; \mathrm{MnCl}_{2} .4 \mathrm{H}_{2} \mathrm{O}, 0.1 \mathrm{~g}$; $\mathrm{FeSO}_{4} .7 \mathrm{H}_{2} \mathrm{O}, 0.1 \mathrm{~g} ; \mathrm{CoCl}_{2} .6 \mathrm{H}_{2} \mathrm{O}, 0.15 \mathrm{~g} ; \mathrm{ZnCl}_{2}, 0.1 \mathrm{~g}$; $\mathrm{H}_{3} \mathrm{BO}_{3}, 0.01 \mathrm{~g} ; \mathrm{Na}_{2} \mathrm{MoO}_{4} \cdot 2 \mathrm{H}_{2} \mathrm{O}, 0.01 \mathrm{~g} ; \mathrm{CuCl}_{2} .2 \mathrm{H}_{2} \mathrm{O}$, $0.02 \mathrm{~g} ; \mathrm{NiSO}_{4} .6 \mathrm{H}_{2} \mathrm{O}, 0.02 \mathrm{~g} ; \mathrm{AlCl}_{3} .6 \mathrm{H}_{2} \mathrm{O}, 0.04 \mathrm{~g} ; \mathrm{NaWO}_{4}$, $0.03 \mathrm{~g}$; and disodium EDTA dihydrate, $0.5 \mathrm{~g}$. CBM was boiled and $3.0 \mathrm{~g} \mathrm{NaHCO}_{3}$ was added after cooling under a stream of oxygen-free $\mathrm{N}_{2}-\mathrm{CO}_{2}(70: 30, \% \mathrm{v} / \mathrm{v})$ gas. The medium was dispensed in $10 \mathrm{ml}$ aliquots into culture tubes under a stream of $\mathrm{N}_{2}-\mathrm{CO}_{2}(70 \%: 30 \%)$, stoppered with rubber septa, sealed with aluminium cap seals (Bellco Glass) and autoclaved at $140^{\circ} \mathrm{C}$ for $20 \mathrm{~min}$. Prior to use, $\mathrm{Na}_{2} \mathrm{~S} .9 \mathrm{H}_{2} \mathrm{O}$ was injected from a sterile stock solution of $25 \mathrm{~g}$ $1^{-1}$ into each tube to give a final concentration of $2.5 \mathrm{mg} \mathrm{l}^{-1}$.

For initiating enrichments, $0.5 \mathrm{ml}$ of sample sediment slurry was added to the CBM medium. Tubes were incubated at $75^{\circ} \mathrm{C}$ for up to 1 week without shaking until xylan solubilization and an increase in microbial numbers was observed. Such enrichment cultures were subcultured four more times and serially diluted in roll tubes containing CBM fortified with $2 \%$ agar (Difco). The roll tubes were incubated at $60{ }^{\circ} \mathrm{C}$ for up to 1 week. Single colonies were picked using sterile Pasteur pipettes and inoculated into fresh CBM medium. This process was repeated four times before the isolate was considered pure as judged by uniform colony morphology and microscopic appearance.

Physiological tests. The modified Hungate anaerobic technique $(12,18)$ was used throughout these studies. Unless indicated, all tests were performed in triplicate.

For $\mathrm{pH}$ and temperature optima studies, CBM with xylose instead of xylan, was used. The effect of $\mathrm{pH}$ on growth was determined in xylose medium containing four different buffers at a final concentration of $50 \mathrm{mM}$ : Walpole's Acetate Buffer (31), $\mathrm{pH}$ range $3 \cdot 7-5 \cdot 1$; MES sodium salt, $\mathrm{pH}$ range 5.5-6.5; Tris (Trizma base), $\mathrm{pH}$ range 6.5-7.5; and $\mathrm{Na}_{2} \mathrm{CO}_{3}$, $\mathrm{pH}$ range $7 \cdot 5-9 \cdot 5$. A stream of $\mathrm{N}_{2}$ instead of $\mathrm{N}_{2} / \mathrm{CO}_{2}(70: 30)$ was used while dispensing medium. The $\mathrm{pH}$ values of the medium after sterilization were $3 \cdot 8-9 \cdot 5$. Cultures were incubated in the optimal temperature.

Gram reaction was determined using a Difco Gram Stain kit according to the manufacturer's recommended protocol (Difco). The effect of sodium chloride $(0-3 \%)$ on growth was determined in CBM containing xylose.

To determine substrate utilization, other carbohydrates replaced xylan in the CBM-based medium. All carbohydrates were added from sterile anaerobic stock solutions to a final concentration of $0.5 \%$. Growth was positive if the optical density was higher than the control carbohydratefree CBM tubes. The ability of the isolate to utilize glucose or xylose as the sole carbon source was tested in CBM lacking xylan and yeast extract. The type strain $C$. saccharolyticus (ATCC 43494) used to compare the substrate spectrum was obtained from the American Type Culture Collection. Generation time of the isolate was determined at the optimum $\mathrm{pH}$ and temperature in CBM containing glucose (final concentration of $0.5 \%$ ).

For antibiotic inhibition studies, CBM containing xylose was used. The ability of the isolate to grow aerobically was determined in CBM which lacked xylan, sodium sulfide and 
$\mathrm{N}_{2}: \mathrm{CO}_{2}$, but contained glucose and air. Aerobic cultures were incubated in Triple Baffled Nephelo culture flasks (Bellco Glass) at $75^{\circ} \mathrm{C}$ and 200 r.p.m. in an Environ-shaker (Lab-Line Instruments). The reduction of nitrate $(10 \mathrm{mM})$, sulfate $(10 \mathrm{mM})$, sulfite $(5 \mathrm{mM})$, and thiosulfate $(20 \mathrm{mM})$ by the isolate was determined in xylan-free glucose CBM medium under anaerobic conditions.

Spore formation was induced using the methods of Schink \& Zeikus (29) and Cook et al. (6). Endospore presence was determined from 1-week- and 1-month-old cultures using the staining method described by Schaeffer \& Fulton (30).

Analytical methods. Growth was measured either by inserting culture tubes directly into a Perkin-Elmer Junior model 35 spectrophotometer and measuring $\mathrm{OD}_{560}$ or by counting cells using a Petroff Hausser counting chamber. Volatile fatty acids were analysed using a Hewlett-Packard $5890 \mathrm{~A}$ gas chromatograph equipped with a flame ionization detector and a Supelco $10 \% \mathrm{SP}-1000,1 \% \mathrm{H}_{3} \mathrm{PO}_{4}$ on $100 / 120$ Chromosorb $\mathrm{W}$-AW packed $6 \mathrm{ft} \times 2 \mathrm{~mm}$ i.d. glass column maintained at $150^{\circ} \mathrm{C}$. Alcohols were also analysed by using a gas-liquid chromatograph equipped with a flame ionization detector and a Supelco $5 \%$ Carbowax 20M on $60 / 80$ Carbopack $\mathrm{B}$ glass column at $120^{\circ} \mathrm{C}$. Lactate was measured enzymically (11). $\mathrm{H}_{2}$ and $\mathrm{CO}_{2}$ were measured using a Carle $\mathrm{AGC}$ series 100 gas chromatograph equipped with an 80/100 silica gel-packed stainless steel column (Supelco) and a thermal conductivity detector. Sulfide was estimated using the method described by Cord-Ruwisch (5).

Electron microscopy. Cells were fixed with cold $2.5 \%$ glutaraldehyde in $0.1 \mathrm{M} \mathrm{Na}{ }_{2} \mathrm{HPO}_{4}-\mathrm{KH}_{2} \mathrm{PO}_{4}(\mathrm{pH} \mathrm{7 \cdot 2)}$ buffer overnight and post-fixed with $1 \%$ osmium tetroxide $\left(\mathrm{OsO}_{4}\right)$. They were then dehydrated with ethanol and embedded in Spurr. Approximately $1000 \AA(100 \mathrm{~nm})$ thick sections were stained with uranyl acetate and lead citrate and examined under a JEOL JEM-100 CX electron microscope at an accelerating voltage of $80 \mathrm{kV}$. Negative staining of cells for electron microscopy was achieved with $1 \%(\mathrm{w} / \mathrm{v})$ uranyl acetate.

DNA base composition. DNA was extracted by the method of Pitcher et al. (23). The buoyant density of purified DNA was measured by ultracentrifugation in a $\mathrm{CsCl}$ density gradient (24). The $\mathrm{G}+\mathrm{C}$ content of the DNA was calculated by using the formula of Schildkraut et al. (28).

165 rDNA sequence studies. Purification of genomic DNA, amplification and purification of the 16S rRNA gene (16S rDNA) from strain $\mathrm{OL}^{\mathrm{T}}$ were performed by previously described techniques $(17,27)$. The purified PCR product was sequenced directly on an ABI automated DNA sequencer by using a Prism Dyedeoxy Terminator Cycle Sequencing kit and protocols recommended by the manufacturer (Applied Biosystems). Ten sequencing primers were used to obtain the sequence which covered approximately $80 \%$ of both strands $(17,27)$. Using the sequence editor, ae2, the 16S rDNA sequence of strain $\mathrm{OL}^{\mathrm{T}}$ was aligned with the $16 \mathrm{~S}$ rRNA gene sequences of various members of the bacterial phyla obtained from the Ribosomal Database Project (19) and from EMBL. Positions of sequence and alignment uncertainty were omitted from the analysis, and pairwise evolutionary distances for 1280 nucleotides were computed. Phylogenetic analysis was performed using programs which form part of the PHYLIP package and include DNADIST (Jukes \& Cantor option), NEIGHBOR-JOINING and DNAPARS (9). Tree topology was re-examined by using 100 boot-strapped data sets for which a script file with the following PHYLIP programs was used: SEQBOOT, DNADIST, FITCH and CONSENSE. Programs in the phylogenetic package MEGA (14) were also used. PHYLIP programs were run on a Sun SPARC workstation and MEGA was run on a Compaq notebook (Contura model 410CX).

\section{RESULTS}

\section{Colony and cell morphology}

Enrichment cultures were obtained after 1 week at $75^{\circ} \mathrm{C}$. A population of heterogeneous rods and filaments were observed in the enrichment cultures. In roll tubes, $0 \cdot 5-2 \mathrm{~mm}$ colonies developed after 1 week at $60{ }^{\circ} \mathrm{C}$. Zones of clearance were observed around the colonies indicating that xylan solubilization had occurred. A single colony in the final serial dilution was picked and designated strain $\mathrm{OL}^{\mathrm{T}}$. Cells of strain $\mathrm{OL}^{\mathrm{T}}$ were straight rods measuring $0.5-0.8 \mu \mathrm{m}$ in diameter and $2-5 \mu \mathrm{m}$ in length, and occurred singly, in pairs, or in chains (Fig. 1a). Small coccoid cells were consistently observed during exponential growth, perhaps because of unequal cell division. Colonies of strain

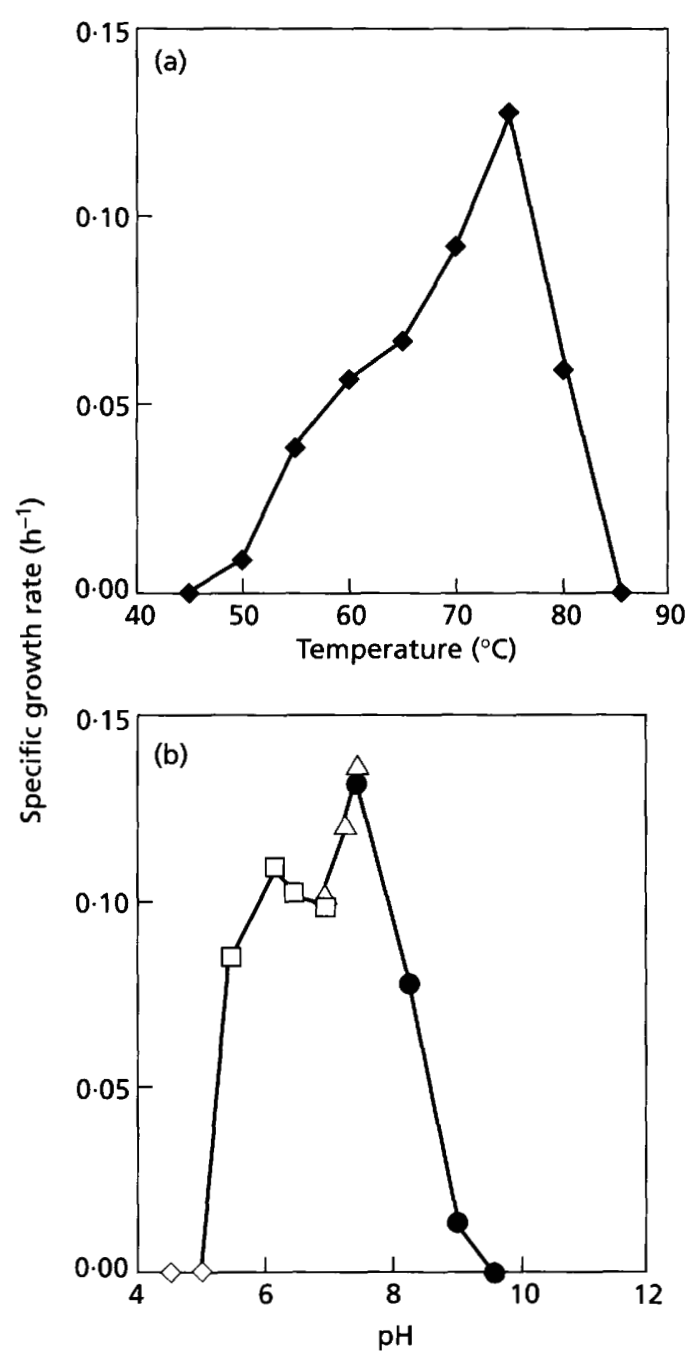

Fig. 2. (a) Effect of temperature on growth of strain $O L^{\top}$. (b) Effect of $\mathrm{pH}$ on growth of strain $\mathrm{OL}^{\top}$. $(\diamond)$ Walpole's acetate buffer; $(\square)$ MES buffer; $(\triangle)$ Tris buffer; $(0)$ sodium carbonate buffer. 


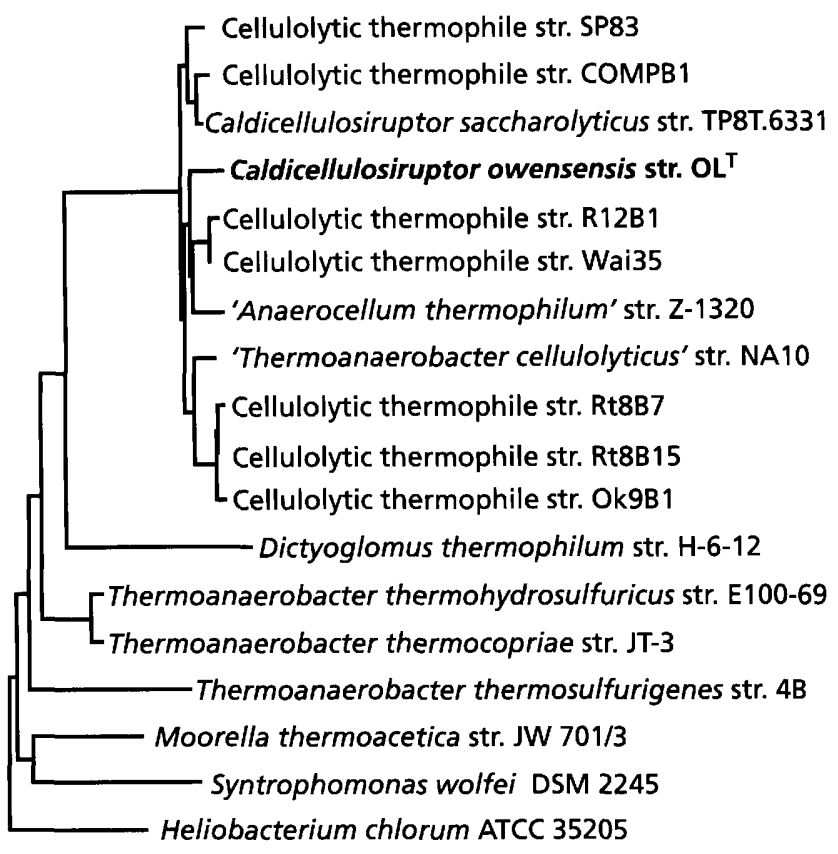

$0 \cdot 10$
Fig. 3. Phylogenetic dendrogram based on 165 rDNA sequence data indicating the position of strain $\mathrm{OL}^{\top}$ within the radiation of members of the genus of Caldicellulosiruptor and related taxa. All the sequences used in the analysis, with the exception of the sequence for the cellulolytic strain SP83 (EMBL accession no. X93020) (22), were obtained from the Ribosomal Database Project, version 5.0 (19). Scale bar indicates evolutionary distance.
$\mathrm{OL}^{\mathrm{T}}$ in roll tubes were circular with smooth edges, up to $2 \mathrm{~mm}$ in diameter, opaque, yellowish and were convex. Strain $\mathrm{OL}^{\mathrm{T}}$ was non-motile and had a Gramnegative reaction, but the cell wall was typical of Gram-positive bacteria as seen by electron microscopy (Fig. 1b). Electron microscopic examination of negatively stained young cells showed the presence of lophotrichous flagella (Fig. 1c). Spores were not observed under any conditions tested.

\section{Growth characteristics and physiology}

Strain $\mathrm{OL}^{\mathrm{T}}$ was a thermophilic, strictly anaerobic, chemoorganotrophic bacterium. The optimal growth temperature of this strain was $75^{\circ} \mathrm{C}$ and no growth was observed below $50^{\circ} \mathrm{C}$ or above $80^{\circ} \mathrm{C}$ (Fig. 2a). Strain $\mathrm{OL}^{\mathrm{T}}$ had a broad $\mathrm{pH}$ range for growth, 5.5-9.0, with an optimum of 7.5 (Fig. 2b). When grown under optimal conditions in xylan-free CBM-glucose medium, strain $\mathrm{OL}^{\mathrm{T}}$ had a doubling time of $7.3 \mathrm{~h}$ and lowered the $\mathrm{pH}$ by 0.5 units. Presence of either yeast extract or vitamins was not required but stimulated growth.

Strain $\mathrm{OL}^{\mathrm{T}}$ could grow on a wide variety of carbon sources including arabinose, cellulose, cellobiose, dextrin, fructose, galactose, glucose, glycogen, inositol, lactose, mannitol, mannose, maltose, pectin, raffinose, rhamnose, ribose, starch, sucrose, tagatose, xylan and xylose but not acetate, arbutin, trypticase peptone, erythritol, glycerol, lactate, melibiose, methanol, pyruvate, sorbitol and trehalose. Autotrophic growth on $\mathrm{H}_{2} / \mathrm{CO}_{2}(80: 20, \%)$ was not observed. Yeast extract could also serve as a sole carbon and energy source.

The end products of glucose fermentation by strain
$\mathrm{OL}^{\mathrm{T}}$ were acetate, lactate, ethanol, $\mathrm{CO}_{2}$ and $\mathrm{H}_{2}$. Nitrate, sulfate, sulfite and elemental sulfur were not reduced.

Strain $\mathrm{OL}^{\mathrm{T}}$ was resistant to $\mathrm{D}$-cycloserin $\left(100 \mu \mathrm{g} \mathrm{ml}^{-1}\right)$, erythromycin $\left(200 \mu \mathrm{g} \mathrm{ml}^{-1}\right)$, and tetracycline $(100 \mu \mathrm{g}$ $\mathrm{ml}^{-1}$ ). Growth was inhibited by penicillin $\mathrm{G}$, streptomycin, chloramphenicol, ampicillin at a concentration of $100 \mu \mathrm{g} \mathrm{ml}^{-1}$. The strain tolerated $0.5 \%$ but was inhibited by $1 \% \mathrm{NaCl}$.

DNA base composition. The genomic DNA base composition of strain $\mathrm{OL}^{\mathrm{T}}$ as determined by the buoyant density of purified DNA in a $\mathrm{CsCl}$ density gradient was $36.6 \mathrm{~mol} \% \mathrm{G}+\mathrm{C}$.

$16 \mathrm{~S}$ rDNA sequence analysis. Using ten primers, 1539 nucleotides corresponding to $E$. coli positions 8-1542 according to the nomenclature of Winker \& Woese (34), were sequenced. Phylogenetic analysis indicated that strain $\mathrm{OL}^{\mathrm{T}}$ was a member of the low-G $+\mathrm{C}$ content sub-branch of the Gram-positive group. Further analysis indicated that strain $\mathrm{OL}^{\mathrm{T}}$ was specifically related to the 11 members of the Caldicellulosiruptor cluster with a mean similarity of $94 \%$. Currently the only taxonomically validated member of the cluster is $C$. saccharolyticus, with which strain $\mathrm{OL}^{\mathrm{T}}$ was related at a similarity level of $94 \%$. Fig. 3 is a dendrogram that was generated by the neighbourjoining method from the evolutionary distance matrix and shows this relationship.

\section{DISCUSSION}

Most thermophilic microbes were isolated from geothermal environments associated with volcanic activity $(8,13,35,36)$. However, other thermally heated 
Table 1. Substrate spectrum of strain $\mathrm{OL}^{\top}$ and other Caldicellulosiruptor species

Strains $\mathrm{OL}^{\mathrm{T}}$ and $C$. saccharolyticus were grown on CBM medium supplied with each substrate tested. Data for $C$. lactoaceticus is from (20). + , Positive; - , negative; ND, not determined.

\begin{tabular}{|lccc|}
\hline Substrate & $\begin{array}{c}\text { Strain } \\
\text { OL }\end{array}$ & C. saccharolyticus & C. lactoaceticus \\
\hline Acetate & - & - & - \\
Cellobiose & + & + & + \\
Cellulose & + & + & + \\
CM-cellulose & + & + & ND \\
Sigmacell 100 & + & + & ND \\
Fructose & + & + & - \\
Galactose & + & + & - \\
Glucose & + & + & - \\
Inositol & + & - & ND \\
Lactose & + & + & + \\
Mannitol & + & - & - \\
Pyruvate & - & - & - \\
Raffinose & + & - & - \\
Ribose & + & - & - \\
Sucrose & + & + & - \\
Trehalose & - & + & + \\
Xylose & + & + & \\
\hline
\end{tabular}

environments including the deep subsurface aquifers, man-made thermal environments and naturally solar heated environments are also reported to harbour thermophilic bacteria $(1,21)$. Strain $\mathrm{OL}^{\mathrm{T}}$ was isolated from a shallow freshwater pond located in the Owens Lake bed area. Owens Lake bed is a largely dry, evaporite deposit at the eastern base of Sierra Nevada in California. Prior to 1910 , the lake was fed by excessive run-off and melted snow from the nearby mountains. After 1910, water was diverted by the Los Angeles aqueduct, and by 1921 the lake entered its present state of periodic flooding and drying. Like the rest of the lake, the sampling site is subjected to periods of drying. It may therefore reach high temperatures during summer, creating a favourable environment for growth of thermophilic microbes.

Strain $\mathrm{OL}^{\mathrm{T}}$ is an extreme thermophile and is a member of the domain Bacteria based on 16S rRNA sequence analysis (8). Furthermore, strain $\mathrm{OL}^{\mathrm{T}}$ degraded xylan and hence could be a member of the genera Clostridium, Thermoanaerobacter, Thermoanaerobacterium or Caldicellulosiruptor. Strain $\mathrm{OL}^{\mathrm{T}}$ was not a sporeformer and hence could not be included as a member of the genera Clostridium or Thermoanaerobacter $(6,7$, 16). Strain $\mathrm{OL}^{\mathrm{T}}$ did not produce sulfur from thiosulfate and hence could be excluded from the genus Thermoanaerobacterium (16). Strain $\mathrm{OL}^{T}$ degraded cellulose and hence possess a similar trait in common with members of the Caldicellulosiruptor group (25). In addition, strain $\mathrm{OL}^{\mathrm{T}}$ had other similarities to this group, including $\mathrm{G}+\mathrm{C}$ content and fermentation endproducts. The taxonomic nature of this cluster is still ill-defined and with the exception of C. saccharolyticus, none of the other members has been taxonomically validated (25).

Another phylogenetically closely related species to strain $\mathrm{OL}^{\mathrm{T}}$ is Anaerocellum thermophilum (32). Strain $\mathrm{OL}^{\mathrm{T}}$ differed in carbon utilization from $A$. thermophilum and $C$. saccharolyticus. Sequencing of the $16 \mathrm{~S}$ rRNA gene and phylogenetic analysis confirmed the placement of strain $\mathrm{OL}^{\mathrm{T}}$ as a member of the Caldicellulosiruptor cluster. Comparison of the phenotypic traits of strain $\mathrm{OL}^{\mathrm{T}}$ with the widely studied members of Caldicellulosiruptor, namely C. saccharolyticus and ' $C$. lactoaceticus' $(25,20)$, indicated that strain $\mathrm{OL}^{\mathrm{T}}$ was nutritionally more versatile and that $C$. lactoaceticus was the least versatile (Table 1). Based on this study we propose that strain $\mathrm{OL}^{\mathrm{T}}$ is the type strain of a new species of the genus Caldicellulosiruptor, Caldicellulosiruptor owensensis.

\section{Description of Caldicellulosiruptor owensensis}

Caldicellulosiruptor owensensis (o.wen.sen'sis. N.L. adj. owensensis from Owens Lake, CA, USA).

Cells are non-motile straight rods that are $2-5 \mu \mathrm{m}$ by $0.5-0.8 \mu \mathrm{m}$, and occur singly, in pairs, or in chains. Lophotrichous flagella. Gram staining reaction was negative. Endospores were not found in any tested conditions. Colonies (diameter, $\leqslant 2 \mathrm{~mm}$ ) are circular with smooth edges, convex, opaque and yellowish. Growth occurred over the temperature range $50-80^{\circ} \mathrm{C}$ with an optimum of $75^{\circ} \mathrm{C}$. No growth was detected at and below $45^{\circ} \mathrm{C}$ or above $80^{\circ} \mathrm{C}$. Alkalitolerant. $\mathrm{pH}$ range, 5.5-9.0 with an optimum at about $\mathrm{pH} 7 \cdot 5$. Growth factors found in either yeast extract or vitamin solutions were not required for growth. Growth was inhibited by penicillin $\mathrm{G}$, streptomycin, chloramphenicol and ampicillin at $100 \mu \mathrm{g} \mathrm{ml}^{-1}$. Cells are resistant to D-cycloserine $\left(100 \mu \mathrm{g} \mathrm{ml}^{-1}\right)$, erythromycin $(200 \mu \mathrm{g}$ $\left.\mathrm{ml}^{-1}\right)$ and tetracycline $\left(100 \mu \mathrm{g} \mathrm{ml}^{-1}\right)$. Growth strictly anaerobic. Chemoorganotrophic. Growth with arabinose, cellobiose, cellulose, dextrin, fructose, galactose, glucose, glycogen, inositol, lactose, mannitol, mannose, maltose, pectin, raffinose, rhamnose, ribose, starch, sucrose, tagatose, xylan, xylose and yeast extract. Does not grow on acetate, amygdalin, arbutin, erythritol, glycerol, lactate, melezitose, melibiose, methanol, pyruvate, sorbitol, trehalose, trypticase peptone or $\mathrm{H}_{2} / \mathrm{CO}_{2}$. The fermentation products from glucose are acetate, lactate, ethanol, $\mathrm{H}_{2}$ and $\mathrm{CO}_{2}$. The bacterium does not reduce nitrate, sulfate, sulfite and thiosulfate. The $\mathrm{G}+\mathrm{C}$ content is $36.6 \mathrm{~mol} \%$ (as determined by buoyant density of purified DNA by $\mathrm{CsCl}$ gradient centrifugation). Type strain $\mathrm{OL}^{\mathrm{T}}$ (= ATCC 700167) was isolated from the Owens Lake in California, USA. 


\section{ACKNOWLEDGEMENTS}

We thank Jean-Louis Garcia for his advice in naming the organism, and Felipe Alatriste-Mondragon for technical assistance. We also thank Birgitta Sjostrand for performing the electron microscopy. Funding came in part from the Australian Research Council (to B.K.C.P.) and is gratefully acknowledged.

\section{REFERENCES}

1. Andrews, K. T. \& Patel, B. K. C. (1996). Fervidobacterium gondwanense sp. nov., a new thermophilic anaerobic bacterium isolated from nonvolcanically heated geothermal waters of the Great Artesian Basin of Australia. Int J Syst Bacteriol 46, 265-269.

2. Angelidaki, I., Petersen, S. P. \& Ahring, B. K. (1990). Effects of lipids on thermophilic anaerobic digestion and reduction of lipid inhibition upon addition of bentonite. Appl Microbiol Biotech 33, 469-472.

3. Bergquist, P. L., Love, D. R., Croft, J. E., Streiff, M. B., Daniel, R. M. \& Morgan, H.W. (1989). Genetics and potential biotechnological application of thermophilic and extremely thermophilic archaebacteria and eubacteria. Biotechnol Gen Eng Rev 5, 199-244.

4. Biely, P. (1985). Microbial xylanolytic systems. Trends Biotechnol 3, 286-290.

5. Cold-Ruwisch, R. (1985). A quick method for the determination of dissolved and precipitated sulfides in cultures of sulfate-reducing bacteria. J Microbiol Methods 4, 33-36.

6. Cook, G. M., Janssen, P. H. \& Morgan, H. W. (1991). Endospore formation by Thermoanaerobium brockii HTD4. Syst Appl Microbiol 14, 240-244.

7. Cook, G. M., Rainey, F. A., Patel, B. K. C. \& Morgan, H. W. (1996). Characterization of a new obligately anaerobic thermophile, Thermoanaerobacter wiegelii sp. nov. Int $J$ Syst Bacteriol 46, 123-127.

8. Daniel, R. M. (1992). Modern life at high temperatures. Orig Life Evol Biosphere 22, 33-42.

9. Felsentein, J. (1993). PHYLIP (Phylogenetic Interference Package) version 3.51c. Department of Genetics, University of Washington, Seattle, USA.

10. Ferguson, T. J. \& Mah, R. A. (1983). Isolation and characterization of an $\mathrm{H}_{2}$-oxidizing thermophilic methanogen. Appl Environ Microbiol 45, 265-274.

11. Gutmann, I. \& Wahlefeld, A. W. (1974). L-(+)-Lactate: determination with lactate dehydrogenase and NAD. In Methods of Enzymatic Analysis, pp. 1464-1468. Edited by H. U. Bergmeyer. Weinheim: Verlag Chemie.

12. Hungate, R. E. (1969). A roll tube method for cultivation of strict anaerobes. Methods Microbiol 3b, pp. 117-132.

13. Kristjansson, J. K. \& Stetter, K. (1992). Thermophilic bacteria. In Thermophilic Bacteria, 1992, pp. 1-18. Edited by J. K. Kristjansson. Boca Raton, FL: CRC Press.

14. Kumar, S., Tamura, K. \& Nei, M. (1993). MEGA: Molecular Evolutionary Genetic Analysis, version 1.0. The Pennsylvania State University, University Park, PA 16802, USA.

15. Lamed, R., Bayer, E., Saha, B. C. \& Zeikus, J. G. (1988). Biotechnological potential of enzymes from unique thermophiles. In Proceedings of the 8th International Biotechnology Symposium, pp. 371-383. Edited by G. Duraned, L. Bobochon \& J. Florent. Paris: French Society for Microbiology.
16. Lee, Y. E., Jain, M. K., Lee, C. Y, Lowe, S. E. \& Zeikus, J. G. (1993). Taxonomic distinction of saccharolytic thermophilic anaerobes: description of Thermoanaerobacterium xylanolyticum gen. nov., sp. nov., and Thermoanaerobacterium saccharolyticum gen. nov., sp. nov.; reclassification of Thermoanaerobium brockii, Clostridium thermosulfurogenes, and Clostridium thermohydrosulfuricum E100-69 as Thermoanaerobacter brockii comb. nov., Thermoanaerobacterium thermosulfurigenes comb. nov., and Thermoanaerobacter thermohydrosulfuricus comb. nov., respectively; and transfer of Clostridium thermohydrosulfuricum 39E to Thermanaerobacter ethanolicus. Int J Syst Bacteriol 43, 41-51.

17. Love, C. A., Patel, B. K. C., Nichols, P. D. \& Stackebrandt, E. (1993). Desulfotomaculum australicum sp. nov., a thermophilic sulfate-reducing bacterium isolated from the Great Artesian Basin of Australia. Syst Appl Microbiol 16, 244-251.

18. Macy, J. M., Snellen, J. E. \& Hungate, R. E. (1972). Use of syringe methods for anaerobiosis. Am $J$ Clin Nutr 25, 1318-1323.

19. Maidak, B. L., Olsen, G. J., Larse, N., Overbeek, R., McCaughey, M. J. \& Woese, C. R. (1996). The Ribosomal Database Project. Nucleic Acids Res 24, 82-85.

20. Mladenovska, Z., Mathrani, I. M. \& Ahring, B. K. (1995). Isolation and characterization of Caldicellulosiruptor lactoaceticus sp. nov., an extremely thermophilic, cellulolytic, anaerobic bacterium. Arch Microbiol 163, 223-230.

21. Mathrani, I. M. \& Ahring, B. K. (1991). Isolation and characterization of a strictly xylan-degrading Dictyoglomus from a man-made, thermophilic anaerobic environment. Arch Microbiol 157, 13-17.

22. Peinemann-Simon, S., Ludwig, W., Vogt, B. \& Gottschalk, G. (1995). Taxonomic analysis of the thermophilic bacterium strain SP83 producing $\mathrm{H}_{2}$ from starch at $75^{\circ} \mathrm{C}$. Syst Appl Microbiol 18, 231-236.

23. Pitcher, D. G., Saunders, N. A. \& Owen, R. J. (1989). Rapid extraction of bacterial genomic DNA with guanidium thiocyanate. Lett Appl Microbiol 8, 151-156.

24. Preston, J. F. \& Boone, D. R. (1973). Analytical determination of the buoyant density of DNA in acrylamide gels after preparative $\mathrm{CsCl}$ gradient centrifugation. FEBS Lett 37, 321-324.

25. Rainey, F. A., Donnison, A. M., Janssen, P. H., Saul, D., Rodrigo, A., Bergquist, P. L., Daniel, R. M., Stackebrandt, E. \& Morgan, H.W. (1994). Description of Caldicellulosiruptor saccharolyticus gen. nov., sp. nov: an obligately anaerobic, extremely thermophilic, cellulolytic bacterium. FEMS Microbiol Lett 120, 263-266.

26. Rainey, F. A., Ward, N. L., Morgan, H. W., Toalster, R. \& Stackebrandt, E. (1993). Phylogenetic analysis of anaerobic thermophilic bacteria: aid for their reclassification. $J$ Bacteriol 175, 4772-4779.

27. Redburn, A. C. \& Patel, B. K. C. (1993). Phylogenetic analysis of Desulfotomaculum thermobenzoicum using polymerase chain reaction-amplified $16 \mathrm{~S}$ rRNA-specific DNA. FEMS Microbiol Lett 113, 81-86.

28. Schildkraut, C. L., Marmur, J. \& Doty, P. (1962). Determination of the base composition of deoxyribonucleic acid from its buoyant density in CsCl. $J$ Mol Biol 4, 430-443.

29. Schink, B. \& Zeikus, J. G. (1983). Clostridium thermo- 
sulfurogenes sp. nov., a new thermophile that produces elemental sulphur from thiosulphate. J Gen Microbiol 129, 1149-1158.

30. Schaeffer, A. B. \& Fulton, M. (1993). A simplified method of staining endospores. Science 77, 194.

31. Sober, H. A. (1968). Handbook of Biochemistry. Cleveland, $\mathrm{OH}$ : The Chemical Rubber Company.

32. Svetlichnyi, V. A., Svetlichnaya, T. P., Chernykh, N. A. \& Zavarzin, G. A. (1990). Anaerocellum thermophilum, new genus new species an extreme thermophilic cellulolytic eubacterium isolated from hot springs in the Valley of Geysers. Microbiology (English translation of Mikrobiologiya) 59, 871-879.
33. Wiegel, J., Mothershed, C. P. \& Puls, J. (1985). Differences in xylan degradation by various noncellulolytic thermophilic anaerobes and Clostridium thermocellum. Appl Environ Microbiol 49, 656-659.

34. Winker, S. \& Woese, C. R. (1991). A definition of the domains Archaea, Bacteria and Eucarya in terms of small subunit ribosomal RNA characteristics. Syst Appl Microbiol 13, 161-165.

35. Zeikus, J. G. (1979). Thermophilic bacteria: ecology, physiology and technology. Enzyme Microb Technol 1, 243-252.

36. Zeikus, J. G., Ben-Bassat, A. \& Hegge, P. W. (1980). Microbiology of methanogenesis in thermal, volcanic environments. $J$ Bacteriol 143, 432-440. 